\title{
Publisher Correction: Cytoplasmic localization of GRHL3 upon epidermal differentiation triggers cell shape change for epithelial morphogenesis
}

\author{
Chiharu Kimura-Yoshida', Kyoko Mochida', Masa-aki Nakaya², Takeomi Mizutani ${ }^{3}$ \& Isao Matsuo (iD ${ }^{1}$
}

Correction to: Nature Communications https://doi.org/10.1038/s41467-018-06171-8; published online 3 October 2018

The original version of this Article contained an error in the labelling of Fig. 4. In panel i, the sixth column was incorrectly labelled as NSC23766 negative, and should have been NSC23766 positive. This has now been corrected in both the PDF and HTML versions of the Article.

Published online: 20 November 2018

\begin{abstract}
(c) (i) Open Access This article is licensed under a Creative Commons Attribution 4.0 International License, which permits use, sharing, adaptation, distribution and reproduction in any medium or format, as long as you give appropriate credit to the original author(s) and the source, provide a link to the Creative Commons license, and indicate if changes were made. The images or other third party material in this article are included in the article's Creative Commons license, unless indicated otherwise in a credit line to the material. If material is not included in the article's Creative Commons license and your intended use is not permitted by statutory regulation or exceeds the permitted use, you will need to obtain permission directly from the copyright holder. To view a copy of this license, visit http://creativecommons.org/licenses/by/4.0/.
\end{abstract}

(C) The Author(s) 2018

\footnotetext{
${ }^{1}$ Department of Molecular Embryology, Research Institute, Osaka Women's and Children's Hospital, Osaka Prefectural Hospital Organization 840, Murodocho, Izumi, 594-1101 Osaka, Japan. ${ }^{2}$ Department of Molecular Biology, Yokohama City University Graduate School of Medicine, 3-9 Fukuura, Kanazawa-ku, Yokohama 236-0004 Kanagawa, Japan. ${ }^{3}$ Department of Life Science and Technology, Faculty of Engineering, Hokkai-Gakuen University, Nishi 11-chome, Minami 26-jo, Chuo-ku, Sapporo, 064-0926 Hokkaido, Japan. Correspondence and requests for materials should be addressed to

C.K-Y. (email: chiharu@wch.opho.jp) or to I.M. (email: imatsuo@wch.opho.jp)
} 